\title{
Kerkleiding in die een en twintigste eeu
}

M J du P Beukes

Sentrum vir Teologiese Navorsing en Toerusting (Afd A)

Universiteit van Pretoria

\begin{abstract}
Church guidance in the twenty-first century

The view of church members relating to the roll of the church, roll overloading and different roll expectations have caused new thinking in the church leadership with a view on the twenty first century. This new thinking is further extended (enlarged) by the nature of post-modernism and various systems of thought. The mission of the church, the priesthood of the laity and the above mentioned factors have resulted in a specific spirituality, knowledge and various skills in regard to the church leaders with a view on the twenty first century.
\end{abstract}

\section{RELEVANSIE VAN DIE TEMA}

Kerkleiding is allerweë onder diskussie. Heitink (1996:30) sê daar word selfs van die kerk se voorgangers as 'voorbijgangers' gepraat, bedoelende 'n funksie wat nie meer noodwendig altyd sal bestaan nie. Hoewel hy nie saamstem met hierdie stelling nie, cordeel hy dat die kerkleiding hoegenaamd nie meer dieselfde aansien het en funksie vervul as in die verlede nie. Sedert 1990 het die Praktiese Teologie baie aandag geskenk aan vernuwing van die bediening. Besinning oor die kerkbediening beteken noodwendig dat daar ook oor die kerkleiding besin sal word (Smit 1995:12). Sedert 1990 het daar in die geledere van die Nederduits Gereformeerde Kerk 'n paradigmaverskuiwing by lidmate ten opsigte van kerkwees plaasgevind. Die tendense wat volgens Arnold Smit (1995:20) voorkom, is egter nie net tot die Nederduits Gereformeerde Kerk beperk nie, maar kom by feitlik alle kerke voor. Die volgende word genoem:

* Gemeentes kan nie meer beskryf word as uniform nie; diversiteit tussen gemeentes en selfs tussen lidmate is 'n alledaagse verskynsel; 
* Sogenaamde hoër gesag, soos gesetel in 'n sinode, word nie sonder meer aanvaar nie. Daar word sterk klem gelê op die outonomie van die plaaslike gemeente. Die moderne selfstandige mens aanvaar nie meer dat besluite van 'bo' af afgeforseer word nie.

* Die lidmate sien die kerk se roeping nie meer primêr as na binne gerig nie, maar as missionêrend van aard.

* Die gemeentes vra na 'n baie meer informele vriendelike bediening. 'n Gemeente se konfessie bepaal nie meer inskakeling nie, maar dit wat 'n gemeente vir sy lidmate bied.

* Gemeentelede is nie meer bereid om objek van die bediening te wees nie, maar wil mede-subjek wees.

Die rol van kerkleiers, veral dié van die predikant, is nie meer so duidelik as in die verlede nie. Oorbelading van die rol en verskillende rolverwagtings wat gewoonlik uitbranding tot gevolg het, is aan die orde an die dag (Van Biljon 1986:40). In sommige kerke bestaan diskrepansie tussen die teologiese opleiding se profilering van die predikant en dié van gemeentes (Shawchuck \& Heuser 1993:23). Volgens Nauta (in Heitink 1996:31) staan die huidige kerkleiding in baie opsigte dwars teenoor die postmoderne kultuur. Die pastor is nie meer die middelaar wat plaasvervangend alles vir almal moet wees nie. Hy is nie sonder meer vir almal herder, leraar en helper nie. Daar word eerder van die pastor verwag om langs mense as vriend te staan. 'Niet het ambt van de predikant, noch haar of zijn professionaliteit, maar eerder de persoon met haar of zijn spiritualiteit staat nu in het centrum van de aandacht' (Heitink 1996:31). Verandering in sienings van die funksie van die predikant wissel so vinnig dat ouer en jonger predikante dikwels totaal verskillende beskouings oor predikant wees het.

De ene dominee hult zich in een gewaad dat tendeert naar het gewijde priesterschap. De ander professionaliseert in therapeutische richting en maak zich onmisbaar als pastor. De derde kiest voor een opwaardering van het leraarschap in de figuur van de theologisch-deskundige. De vierde wordt schriftgeleerde of rabbi. De vijfde profileert zich als druk baasje of manager.

(Heitink 1996:30) 
Gemeentelede se beskouings verskil in hierdie verband in so 'n mate dat daar nie meer so iets bestaan soos 'n beskrywing van die bediening wat die meerderheidsbeskouing verteenwoordig nie. 'Verskillende individue, groepe en kerke het hulle eie konseptualisering op grond waarvan geoordeel word of 'n persoon geskik is vir die amp of nie. Die spanning tussen "sein" en "sollen" lei tot die identiteitskrisis waarin predikante vandag verkeer' (Van Arkel 1986:32).

Volgens Norman Shawchuck en Roger Heuser (1993:21) is daar wêreldwyd iets radikaal verkeerd met die professie van die predikant. Om in die bediening te oorleef, is eerder die uitsondering as die reël. Egskeidings onder predikante is besig om die hoogte in te skiet. Daar is meer predikante as ooit in die gevangenis. Meer predikante as ooit bedank uit die bediening.

Erosie van predikante is in die Nederduitsch Hervormde Kerk van Afrika nie 'n vreemde verskynsel nie. Tussen 1985 en 1993 het nie minder as 53 predikante die bediening verlaat nie (Verslag 1996:3). 'n Deeglike ondersoek van die Hervormde Kerk se Raad vir Herderlike Sorg het onder andere die volgende aspekte uitgewys as faktore wat aanleiding tot die bedankings gee:

* 'n Gebrek aan teologiese en nie-teologiese kritiese vaardighede wat nodig is vir die bediening;

* die gereedheid van die Algemene Kommissie en Ringskommissies om eerder te tug as om goeie werk te erken en ondersteuning te bied;

* meerdere vergaderings en kommissies word verdink van politieke sydigheid en teologiese ortodoksie;

* die kerk word as te konserwatief beleef met betrekking tot sy bedieningstrategieë aan die moderne mens met sy eie geloofsbelewenis en uitlewingsbehoeftes; .

* aan kerkrade word geen ruimte gelaat om self te besluit oor sake soos die liturgie en die sang van jongmense en kinders nie;

* met die vaag omskrewe take van predikante en hulle eggenotes vind predikante dit moeilik om te voldoen aan die verwagtings wat ten opsigte van hulle gekoester word. 
Op vaardigheidsvlak word veral die volgende beleef:

* 'n Onvermoë om goeie verhoudings met lidmate en kollegas op te bou en te behou, veral met dié wat krities teenoor die predikant en sy funksionering is;

* die predikant se oorheersende styl en oormatige selfhandhawing wek weerstand by lidmate (Verslag 1996:3-7).

In die lig van bo genoemde beleef die predikante self groot onsekerheid ten op sigte van hulle bediening. Dit word verder vererger deur die veranderende samelewingspatrone binne en buite Suid-Afrika. Enersyds oordeel lidmate dat vir ewig in die ou gebaande weë gebly moet word, en andersyds word geoordeel dat die kerk voortdurend volgens die eise van die Woord en in die lig van die omstandighede moet hervorm. Dit is nie altyd binne die predikante se vermoë om hierdie proses te hanteer nie.

\section{KERKRKLEIDING IN KONTEKS}

Kerkleiding vind nie in 'n vakuum plaas nie, maar in konkrete realiteite - op 'n bepaalde plek en in ' $n$ bepaalde tyd. Hierdie plek en tyd is egter nie los te maak van die res van die wêreld en tyd in die algemeen nie. 'Tydsgees is nie konteksloos nie en is ook nie net plaaslik van aard nie, maar is wêreldwyd waarneembaar. Dit is ingebed in godsdienstige strukture en tegelykertyd ook in ekonomiese, politieke en kulturele instellings' (Van Aarde 1993:6).

Tradisioneel word onderskei tussen drie kultuurparadigmas: die pre-moderne, die moderne en die post-moderne:

* In die pre-moderne kultuurparadigma het godsdiens en politiek, kerk en kultuur met mekaar in alliansie gegaan en feitlik in mekaar opgegaan. Alles is so verchristelik en verkerklik dat selfs van 'n ekklesiokrasie gepraat kan word. Aan die ander kant is dit duidelik dat die Griekse filosofie en die Romeinse reg 'n duidelike stempel op die denke en optrede van die Kerkvaders en die kerk in die algemeen gelaat het.

* In die moderne era vorm die basiese onderskeiding van subjek en objek die grondslag vir die subjekgesentreerde rede, wat die pre-moderne era geleidelik verdring. Die kennende subjek met sy logiese denke voer nou die botoon (Steenkamp 1997: 6). In die na-oorlogse era bring die elektroniese media die kerk in kontak met feit- 
lik die ganse wêreld. Hierdie kontak en blootstelling dra daartoe by om kulturele en godsdienstige grense al hoe meer te laat vervaag (Dijkstra-Algra \& Vizeede Kruik 1996:10). Sekularisme, materialisme, pragmatisme en individualisme word dan algemene samelewingstendense. Die modernisme het volgens Voster (1993:5) bepaalde gevolge vir die kerk. Enersyds bring dit die histories-kritiese teologiese beoefening na vore en andersyds kleef dit aan die fundamentalisme en die konfessionalisme vas. Enersyds is daar ruimer denke en uitlewing van die kerklike praxis en andersyds 'n groter mate van vasklewing aan die tradisionalime. Teenoor die beoefening van 'n pragmatiese etiek word die vasklewing aan 'n tradisionele Biblisistiese etiek aangetref.

* Aangesien die post-moderne paradigma die mees algemene kultuur en denkpatroon aan die begin van die een en twintigste eeu sal wees (Armour \& Browning 1995: 111), vra dit veral ons aandag. Die moderne kultuur is egter nie sonder meer deur die post-moderne afgeskryf nie, maar het 'n kritiese metgesel daarvan geword. Hierdie kultuur se tendens is nie om af te skryf nie, maar om alle denke te akkommodeer. Dit wil die aard van die huidige werklikheid in sy totaliteit beskryf. Pluraliteit het die model vir denke en handeling geword, en geen standpunt is meer absoluut dominant nie. Dit wil 'die pragmatiese en affektiewe dimensie van menswees naas die kognitiewe beklemtoon' (Van Aarde 1993:6). Volgens hierdie stroming benader mense die werklikheid vanuit 'n bepaalde vooronderstelling waardeur hulle lewenswyse en wetenskapsbeoefening bepaal word. 'Elke mens moet daarom die reg gegun word van eie voorveronderstellings van watter aard ook al' (Voster 1993:6).

Hierdie sisteem vra dat die mens 'endlessly flexible' sal wees. Die postmodernisme benader die wêreld met 'n wye lens en vra vir die akkommodering van alle standpunte. In plaas daarvan om teen mekaar te werk, word 'n appél gemaak vir samewerking onder alle omstandighede (Armour \& Browning 1995:113). Die model van objek-subjek word deur die post-modernisme vervang met 'n sisteem van subjeksubjek. 'Dit lei in die eksistensiële denke daartoe dat die klem op die mens as verhoudingswese geplaas word' (Steenkamp 1997:8).

Vir die kerklike bediening het die post-modernisme positiewe sowel as negatiewe gevolge. Positief bied dit, naas die kognitiewe, ruimte vir die affektiewe, die konatiewe en die psigomotoriese. Dit bied ook ruimte vir diversiteit op feitlik elke terrein van die bediening, die teologiese beskouings, die bedieninge en veral die liturgie waaraan daar ' $n$ groot behoefte is. 'Negatiewe aspekte van die post-modernisme lê daarin 
dat die bestaan van absolute waarhede ontken word. Waarhede kan hoogstens relatief wees en kan na gelang van omstandighede gewysig word. Alle standpunte het reg op bestaan en alle godsdienste word verdra' (Voster 1993:7).

Clare W Graves, 'n ontwikkelingsielkundige van New York Union College, het 'n leeftyd bestee aan navorsing oor die verskynsel van diversiteit onder mense. In April 1974 het hy sy basiese bevindinge in 'n artikel, 'Human nature prepares for a momentous leap' in The Futurus gepubliseer. Hoewel Graves aanvanklik 'n groot aanhanger van Maslow se teorieë was, is sy denke geheel en al nuut. Volgens Graves is daar agt denksisteme en elkeen van hierdie sisteme bepaal 'n afsonderlike lewensuitkyk. Die volgende algemene beginsels geld van hierdie denksisteme:

* Met geboorte is al agt sisteme latent by elke mens teenwoordig. Hulle funksioneer die een na die ander op verskillende stadia van die mens se lewe;

* alhoewel aspekte van al agt sisteme by iemand kan voorkom, domineer een of twee sisteme;

* sisteme verskil van persoon tot persooon;

* sisteme verander gedurende die mens se verskillende lewensfases sonder dat ' $n$ bepaalde sisteem noodwendig in 'n sekere lewensfase voorkom; en

* in 'n gemeenskap is daar gewoonlik persone van verskillende sisteme teenwoordig, maar een of twee is dominant.

Graves het nie vir elkeen van sy sisteme 'n naam gegee nie, maar hy noem hulle gewoon sisteem een, twee, drie ensoyoorts. Vanweë die wesenlike belang van hierdie sisteme om die mens van die een en twintigste eeu te verstaan, beskryf ek elkeen van hierdie sisteme baie kortliks.

\section{Sisteem 1}

Hierdie sisteem is gedurende die mens se eerste lewensjare dominant. Die kernaspek van hierdie sisteem is fisiese oorlewing. Dit is gedurende die mens se eerste lewensjare dominant, maar kom van tyd tot tyd weer na vore, afhangende van 'n persoon se fisiese omstandighede. In agtergeblewe gemeenskappe is hierdie die dominante sisteem. 


\section{Sisteem 2}

Die lewe van ' $n$ mens gedurende sisteem 1 is onseker. Baie dinge gebeur waarop jy as kind nie 'n antwoord het nie. Dit het volgens Graves noodwendig gelei tot die denksisteem van 'n ander wêreld met ander magte - 'n wêreld van fantasie met feëtjies, maar ook met monsters. Die vraag na die oorsaak van onverklaarde gebeure het in die primitiewe gemeenskap gelei tot die oortuiging dat gode vanuit 'n ander werklikheid die bepalende faktor is.

\section{Sisteem 3}

Vir klein geïsoleerde stamme het dit spoedig geblyk dat die gode van die ander werklikheid nie altyd in hulle basiese behoeftes van kos en klere voorsien nie. Met die oog op oorlewing, is beweeg na sisteem 3, naamlik fisiese krag. In sisteem 3 geld die reël dat mag die bepalende faktor is. Die sterke oorleef en die swakke gaan onder. Wenners bepaal die reëls. Waar sisteem 2 stamme gebou het, het sisteem 3 koninkryke gebou, byvoorbeeld Assirië, Babilon, Griekeland, Rome, Duitsland en Amerika. Om sy krag te maksimaliseer, verban sisteem 3 so ver as moontlik enige denke van sisteem 2 en gebruik dit en ander sisteme net as dit tot sy eie voordeel kan dien. Die denke van sisteem 2 is vir hulle niks anders as 'n teken van swakheid nie. Kenmerke van sisteem 3 se denke is onder andere: selfgesentreerdheid, hiërargiese strukture, dehumanisering van mense, selfvergenoegdheid, eiesinnigheid, alleenbesitters van die waarheid en 'n gebrek aan kommunikasievermoeë. Sisteem 3 is egter nie net negatief ingestel nie. Sisteem 3 se styl is soms noodsaaklik as dit kom by sake soos die beoefening van sport, streng optrede met die oog op die deurvoering van 'n belangrike saak en die toepassing van reg en geregtigheid. 'In summary, system 3 is absolutely essential to personal and cultural achievement. At the same time, it is potentially more dangerous than any other system' (Armour \& Browning 1995:73).

\section{Sisteem 4}

Sisteem 4 het ongeveer 3000 jaar gelede reeds sy beslag gekry. Dit is die dominante tendens in die Romeinse reg, die Joodse Talmud en die Christelike etiek. Sisteem 4 het 'n alternatief gesoek vir sisteem 3 se geweld en dit gevind in 'n sisteem van morele beginsels en gedragskodes. Dit streef na prinsipes, morele kodes waarmee almal hulle kan vereenselwig. Tyd speel ' $n$ baie belangrike rol in sisteem 4. Historisiteit bepaal in 'n groot mate die legitimiteit van gedragskodes. Verandering het hier geen plek nie. Institusionaliteit speel 'n groot rol. In sommige gevalle word die instituut so belangrik geag dat dit bo morele kodes gestel word. Dit streef na homogeniteit en konformiteit. Diversiteit word in alle opsigte afgewys. Stabiliteit is volgens hierdie sisteem slegs moontlik as almal dieselfde dink en doen. Slegs diegene wat bereid is om volkome in te pas by die algemene morele kodes, word as 'true believers' aanvaar (Armour \& 
Browning 1995:82). Hulle motto is: Elkeen wat nie met ons is nie, is teen ons - ons versus hulle. Alles is of wit of swart. Grys word gereken as deel van die negatiewe en die verkeerde.

Bestuur beteken vir sisteem 4 'n hierargie van bo na onder. Net soos in sisteem 3 word die reëls deur die topbestuur gemaak en almal is verplig om daarby in te val. Die onderdane het ook nie ' $n$ probleem om in te val nie, aangesien gehoorsaamheid ' $n$ sentrale deel van hulle morele kodes is. Sisteem 4 is so swaar belas met reëls, regulasies, presiese prosedures, die etos van die instelling en outoritêre gesag dat daar nie sprake van 'compassion' is nie (Armour \& Browning 1995:85). Hier staan die morele kodes in die sentrum en nie die mens nie. Volgens Armour \& Browning (1985: 86) was sisteem 4 vir baie lank die styl van die meeste Reformatoriese kerke.

\section{Sisteem 5}

Sisteem 5 het in die dertiende en veertiende eeu sterk na vore gekom. Dit is in 'n sekere sin 'n teenreaksie op die denke van sisteem 4. Daar het 'n strewe ontstaan na vryheid, openheid, diversiteit, kreatiwiteit, beweging en effektiwiteit. Sisteem 5 se basiese uitgangspunt is: Enige iets wat die moeite werd is om gedoen te word, moet deeglik en professioneel gedoen word. Vir sisteem 5 is die waarheid nie geleë in een enkele historiese bron nie, maar in alle historiese en relevante bronne. 'n Bepaalde sisteem of etos word nie op grond van historisiteit gehandhaaf nie, maar op grond van effektiwiteit omdat, so word gesê, dit vir my effektiewer is. Naas effektiwiteit speel diversiteit 'n belangrike rol. Die individu, en nie die gemeenskap nie, staan in die middelpunt. Almal is gelyk en het regte. Net soos met sisteem 4, het hierdie sisteem ook 'n groot invloed op kerke en geloofsgemeenskappe uitgeoefen. In teenstelling met sisteem 4 word die klem nie geplaas op die leer van die kerk nie, maar op die lewe. Mense by wie sisteem 5 se denke oorheersend is, streef nie na godsdiens wat bloot aangehang word omdat dit tradisioneel is nie. Hulle luister na preke en raak betrokke by Bybelstudies as dit na vorm en inhoud vir hulle relevant is met betrekking tot hulle lewe van elke dag. Die godsdiens van sisteem 5 se mense toon baie sterk individualistiese tendense en daarom verkies hulle in baie gevalle klein huisgemeentes of groot mega kerke waar die individu in die massa verdwyn.

\section{Sisteem 6}

Sisteem 6 poog om die slagoffers van al die ander sisteme op te tel. Dié sisteem is egalitaries van aard. Dit streef na koalisie, konsensus en nie na magspiramides nie. Dit neem die saak op van diegene wat geen mag en aansien het nie. Hieruit spruit fei lik alle pogings voort vir regstellende aksies rakende vroueńs, kinders, agtergeblewenes en ander wat ter sprake is. Eksklusivisme van enige mens of groep funksioneer nie in hierdie sisteem nie. Dit kommunikeer en luister in dieselfde mate na gevoelens as na 
standpunte. Dit doen 'n appél op geestelik sensitief ingestelde mense en loods van daaruit aksies om mense in nood te help. 'Compassion' is deur en deur die sentrale motief van hierdie sisteem. Die mense van sisteem 6 wil graag betrokke wees by die kerk. Hulle vra egter na 'n klemverskuiwing: 'n regmatige plek vir barmhartigheidsdiens naas Woordbediening, Woordbediening waar die klem sterker op die affektiewe as die kognitiewe geplaas word en offergawes wat in die eerste plek aangewend word vir die nood van mense en nie vir die instandhouding van geboue nie. Hulle verlang 'n kerk met 'n warm, akkommoderende atmosfeer en 'n hart vir diversiteit. Hierdie diversiteit strek ongelukkig dikwels net sover as die mense wat min of meer dieselfde as hulle dink. Persone met ander konsepte word gewoonlik nie geakkommodeer nie. Hulle omgee is daarom beperk en is in 'n sekere sin 'n vorm van arrogansie en die vorming van eksklusiewe kleingroepe kom dikwels voor.

\section{Sisteem 7}

Sisteem 7 en 8 se denke sal waarskynlik oorheersend wees in die begin van die een en twintigste eeu. Sisteem 7 se uitgangspunte stem in 'n groot mate ooreen met dié van die post-modernisme. Sisteem 7 soek nie oorsaak-gevolg antwoorde nie. Antwoorde word nie sonder meer beskou as voor-die-hand-liggend nie, aangesien daar gewoonlik 'n reeks moontlike antwoorde is. Niks word as vasstaande beskou nie. Alles is buigbaar en daar word na alle moontlike komponente gekyk voordat 'n antwoord gegee word. Die benadering is deurgaans holisties en daar word gepoog om al die sisteme te akkommodeer. Vir die denkers van sisteem 3 en 4 is die kerkleiding gewoonlik outoritêr van aard. Sisteem 5 en 6 se kerkleiers aan die ander kant, is meer egalitaries van aard. Sisteem 7 sien kans om beide leierskapstyle te akkommodeer en dit is volgens Armour \& Browning (1995:117) in ooreenstemming met die apostel Paulus se konsep van kerkleierskap.

\section{Sisteem 8}

Sisteem 8 is 'n sisteem in wording. Dié sisteem kyk na die totale planeet as 'n lewende eenheid. Vir die denkers van sisteem 8 verdwyn alle politieke en etiese verskille. Die hele mensheid vorm volgens hulle insigte ' $n$ eenheid waar almal in liefde en harmonie kan saamleef.

Naas die algemene denkpatrone en kultuurvorme, moet kerkleiers in Suid-Afrika ook nog rekening hou met die situasie van die land en van elke gemeente afsonderlik. SuidAfrika is huidig 'n veranderende land, 'n nuwe wordende land. Eeu-oue denkpatrone 
en tradisies is besig om te verander. Tradisionele strukture en afgrensing tussen volke, rasse en groepe is op sommige plekke besig om plek te maak vir 'n multikulturele gemeenskap. Daar bestaan nie meer 'n owerheid wat Christelike waardes by wyse van wetgewing beskerm nie. Godsdiensonderrig op skool is besig om te verdwyn. Regstellende aksies lei tot verhoogde belasting, afplatting van lewenstandaarde, werkloosheid, verhoogde inflasiekoers en dit alles het armoede tot gevolg (Dreyer 1996:188). Die oop sisteem en beter verhouding tussen blank en swart lei daartoe dat blankes al hoe meer bekend en gemoeid raak met die geweldige armoede en maatskaplike nood waarin swart mense in die 'townships' verkeer. Die totale finansiële en maatskaplike opset van die land skep by baie mense onsekerheid (Louw 1996:36). Op Suid-Afrikaanse bodem is dit veral die navorsing van Boshoff (1990:21) wat besonder bruikbare gegewens op die tafel geplaas het. Hy toon die volgende aan as feitlik algemene tendense van die Suid-Afrikaanse samelewing:

* enkelouers;

* afwesige vaders en moeders;

* rolverwarring;

* groot diversiteit in waardesisteme;

* afwesigheid van uniforme lidmate en gemeenskappe;

* bevraagtekening en selfs die omvêrgooi van tradisies;

* toeganklikheid tot ander kulture en godsdienste en groot onsekerheid oor die toekoms.

\section{KLEIDING IN KONTEKS}

Watter eise stel die moderne tyd, spesifiek die konkrete situasie van Suid-Afrika aan die kerkleiding? Hoedanig behoort die kerkleiding aan die begin van die een en twintigste eeu daaruit te sien? Hierdie vraag sal prakties-teologies beantwoord moet word in die lig van prinsipiële, historiese en praktiese (kontekstuele) data. Veral sal daar verder besin moet word oor die volgende aspekte: die roeping van die kerk, dienswerk van die gelowiges, spiritualiteit, leierskapstyle, visionering en strategiese teologiese beplanning.

\subsection{Roeping van die kerk}

Christelike leierskap is die Godgegewe gawe om mense te beinvloed om in Christus, die Hoof van die kerk, te glo en sy wil met die kerk tot uitvoer te bring (Stevens \& Collins 1993:109). 'Die wese van die kerk is die Heer van die kerk. Die kerk is die 
aardse liggaam van Jesus Christus, wat sy hemelse Hoof is. Die kerk is Christelike kerk of dit is nie kerk nie' (Van der Westhuizen 1990:543). Goeie kerklike leierskap hang daarom nie af van hoeveel mense die leier aan homself gebind het nie, maar aan Jesus Christus. Die kerkleier se verstaan van die kerk se roeping is onlosmaaklik verbonde aan sy/haar menswees teenoor God, teenoor ander mense en teenoor die wêreld - die wyse waarop hy/sy kerkleier is.

Hoewel die begrip apostolaat duidelik ingeskryf is in die Hervormde Kerk se wette en bepalings en elke kerkleier weet dat dit deel van die kerk se roeping is, kom daar op gemeentelike en sinodale vlak nie veel van tereg nie (Van der Merwe 1996:1).

Die roeping van die kerk is en bly die verheerliking van God, die soeke na sy koninkryk en die bekendmaking van hierdie koninkryk aan die wêreld. Die gemeente is alleen maar gemeente in perspektief van die koninkryk, anders is dit nie gemeente nie (Nel 1994: 25). 'Dit is die missio Dei - God se bemoeienis met die wêreld om deur die verkondiging van Jesus Christus as die gekruisigde en opgestane Heer mense tot geloof en verlossing te bring sodat hulle sal lewe tot eer van God. Die kerk is nie 'n doel op sigself nie, maar ' $n$ eiesoortige gemeenskap in diens van God se missio Dei' (Coetzee 1996:11). In beide die Ou en die Nuwe Testament staan God se gerigtheid op die nasies sentraal. (Sien in hierdie verband onder andere Jesaja 49:6 en Matteus $28: 19,20$ ). Barth stel dit ook dat die kerk bestaan in sy gestuur wees en in die opbou van homself ter wille van sy gestuurdheid (Bosch 1991:372). Van hieruit oordeel Coetzee (1996:9) en andere dat die missionêre nie net 'n kenmerk van die kerk is nie, maar die wese van die kerk.

The church is mission. It does not have missions as one of its many optional activities. It does not exist for itself, its own glory, its own selfimprovement, or even its own mission. The body exist for God and God's purpose in the world. We must be willing to do with our own corporate life what Christ did with his body in love for the world - to interpose its life for the healing and salvation of others. But we can do and be this only because we find our meat and drink in doing the Lord's will and being in Christ.

(Stevens \& Collins 1993:127, 133)

Hierdie in Christus wees, om in gehoorsaamheid gestuurde van God te wees, vra toerusting, opbou in die geloof. Dit bring mee dat met die oog op die missionêre, die kerk se funksie tweeledig is, naamlik om uit te bou en op.te bou; dit moet na buite en na binne gerig wees. 


\subsection{Dienswerk van die gelowiges}

Reeds in 1960 het Hendrik Kraemer baie duidelik aangetoon dat dit die kerk se taak is om die gelowiges toe te rus om die roeping van die kerk in die wêreld tot uitvoer te bring. Hierdie visie van Kraemer het allermins, veral nie in die Nededuitsch Hervormde Kerk gerealiseer nie. Die resultaat is oorlaaide pastors en gefrustreerde lidmate omdat daar nie vir hulle voldoende geleentheid in die kerk is om te doen wat volgens die Bybel hulle roeping is nie. Die lidmaat van die dag neem nie meer genoeë met outoritêre kerkstrukture en ignorering van hulle Godgegewe gawes nie. Sisteem 5, 6 en 7 se denkers se wese is van so 'n aard dat hulle self betrokke wil wees, veral om binne die strukture van die kerk die geleentheid te hê om mee te werk aan die nood en die krisisse waarin mense hulle bevind.

Stevens \& Collins (1993:89) oordeel dat veral die Reformatoriese kerke 'n groot fout maak deur te dink dat lidmate daar is om die pastor te help om sy taak tot uitvoer te bring. Volgens Efesiërs 4 en ander Bybelgedeeltes is die omgekeerde waar: Die pastor is daar om die lidmate te help om hulle taak tot uitvoer te bring. Lekkerkerker (1971:129) huldig dieselfde standpunt as Stevens en Collins. Hy verwys na Luther wat sou gesê het: ' $\ldots$ wat uit de doop omhoog gekropen is, dat mag zich beroemen, dat het reeds tot priester, bischop en paus is gewijd.' Prakties is dit baie makliker 'to put ten men to work than to do the work of ten men' (Stevens \& Collins 1993:75). Alhoewel die diensgroepstelsel in die Nederduitsch Hervormde Kerk meegehelp het om 'n groot getal lidmate te bemagtig met dienswerk, is met hierdie stelsel nog nie werklik daarin geslaag om gemeentes se gelowiges tot uitvoer van hulle dienswerk in die wêreld te bring nie. Al die bestaande bedieninge sal met die oog hierop benut moet word. Naas dit, sal besondere toerustingsgeleenthede en materiaal vir hierdie geleenthede geskep moet word. Die tyd hiervoor was nog nooit meer geleë as hier aan die begin van die een en twintigste eeu nie. Enersyds bied die verwydering van skeidsmure tussen mense die geleentheid om met woord en daad alle mense te bereik. Andersyds is die mens van die komende eeu bereid om na alle standpunte te luister - die evangelie word nie sonder meer afgewys nie. Die geweldige armoede in ons land gee juis vir alle lidmate by hulle werk- en woonplek die geleentheid om barmhartigheidsdiens te bewys. Dit wat baie mense as bedreigings sien, moet eerder gesien word as geleenthede wat vir elke gelowige gebied word. Om gestalte te gee aan die oortuiging dat die gelowiges nie in die eerste plek arbeidsveld is nie, maar arbeidsmag, sal daar 'n denkklimaat veral onder die kerkleiding gevestig moet word. 


\subsection{Spiritualiteit}

Huidig word oor 'n breë linie in teologiese kringe oor spiritualiteit gepraat. (kyk o a Stevens \& Collins 1993:110-118; Shawhuck 1993:39-57; Van der Merwe 1995:5-36; Smit 1995:36-51). Dit is waarskynlik so omdat 'n gebrek aan spiritualiteit een van die grootste leemtes in die lewe van lidmate en kerkleiers is (Van der Merwe 1995:1).

Wat is spiritualiteit? 'Dit is die wyse waarop mense hulle verhouding met die Here verstaan en uitleef' (Van der Merwe 1995:1). 'Dit is een modus van het leven. Het is een bepaalde wijse van bestaan' (Van de Beek 1996:3). 'Dit is jou totale wees en lewe voor die aangesig van God in Christus deur die werking van die Heilige Gees' (Smit 1995:35). Dykstra-Algra (1996:23) stel dit heel prakties:

Spiritualiteit heeft in ieder geval te maken met de ervaringskant van het geloof, met de geloofsbeleving. Wat geloof ik eigenlijk zelf? Wat houdt mijn geloofsleven van alledag in? Hoe speelt dat een rol in de gemeente? Wat heeft mijn taak te maken met de kernen van mijn geloof? Waar doe ik het allemaal voor? Waar haal ik mijn inspiratie vandaan? Wat houdt mijn gaande?'

Hierdie lewe voor die aangesig van God kan nie in kompartemente ingedeel word nie. Kerkleiers is nie in die bediening besig en het naas dit ' $n$ bepaalde spiritualiteit nie. Spiritualiteit is ingeweef in wat die kerkleier op die markplein en die kerkplein is. Spiritualiteit word nie in 'n lugleegte uitgeleef nie, dit vind in die wêreld van die een en twintigese eeu plaas. Spiritualiteit is daarom volgens Van de Beek (1996:5) die in staat wees om midde-in die gefragmenteerde lewe van hierdie tyd deur die leiding van die Heilige Gees te lewe. Vir die teologiese opleiding het dit die implikasie dat gepoog sal word om aan toekomstige kerkleiers antwoorde te gee, hoe om in die gekompliseerde samelewing met hulle eie lewe voor te leef.

Die belangrikste eienskap van ' $n$ kerkleier is nie wat hy/sy doen nie, maar wat hy/sy is. Omdat die samelewing primêr funksioneel is, word die klem gewoonlik op doen en nie op wees geplaas nie. Volgens Smit (1995:36) hang effektiewe kerkleierskap in 'n mindere mate af van aangeleerde tegnieke en meer van geinternaliseerde gewoontes of waardes. Mense word die sterkste beïnvloed deur dit wat hulle in die lewe van 'n kerkleier sien.

As 'n etiese lewenswyse in die gewone gang van ons lewe nie mense trek en nuuskierig maak nie, sal ons met 'n beplande bediening - al word 
dit ook hoe noukeurig en kundig uitgewerk, nie 'n hond haaraf maak nie. God skep die mens na sy beeld. Dit beteken onder andere God wil hê dat mense mekaar aan Hom sal herinner. Soos wat Christus God by ons verteenwoordig, moet ons Hom by mense verteenwoordig.

(Smit 1995:39).

'The most important thing a pastor brings to the spirituality of the congregation is his or her own experience and example. Spirituality is more caught than taught' (Shawchuck \& Heuser 1993:125). Eers as die kerkleiers se verhouding met die Here, hulle lewensmaats en hulle kinders in orde is, en hulle eie lewens getuig van 'n gehoorsame lewe aan God, kan hulle vir die gemeente sê dit is die manier van doen.

Kerkleiers se spiritualiteit kom in die besonder tot uitdrukking in hulle optrede teenoor ander mense. Kerkleiers moet anders begin dink oor mense. Die leiers staan nie teenoor die gemeente en ander mense nie, maar saam met hulle. Lotsverbondenheid is nodig. Sodra kerkleiers en die gemeente begin om saam met mekaar te leef, raak hulle lief vir mekaar. As kerkleiers lief is vir mense en hulle deur die oë van God sien, is dit vir hulle ook moontlik om die positiewe in ander raak te sien en om entoesiasties oor hulle te raak. Die belangrikste verwagting wat lidmate van kerkleiers het, is 'n positiewe benadering ten opsigte van hulle (Smit 1995:44). In die lig hiervan oordeel Callahan (1986:25) tereg dat 'compassion' die sterkste motiveerder van lidmate is. Kerkleiers is nie net saam met ander nie, maar ook daar vir ander. Leiers se dienswerk moet daarom minder amptelik en meer humaan wees. Die leiers se menslikheid moet in alle aspekte van die bediening sigbaar wees. Hierdie gesindheid teenoor mense is net moontlik as die regte spiritualiteit by die kerkleiers voorkom. Egte teenwoordigheid by mense is nie ' $n$ saak van tegniek nie, maar van spiritualiteit. Kerkleiers kan eers regtig by mense teenwoordig wees as hulle vanuit die oortuiging leef dat God met hulle is en hulle met God. Egte teenwoordigheid by mense vra dat kerkleiers 'n gees van egtheid en nederigheid sal openbaar.

Kerkleiers moet hulleself wees en nie rolle vertolk nie. Daar moet afgesien word van 'n 'sterkman-wennerstyl'. Om wonde te hê, is nie noodwendig 'n diskwalifikasie as jy vir die Here wil werk nie. Ons het nie nodig om ons wonde weg te steek nie. Die Here vra nie ons moet onsself beter, sterker, gesonder, of heiliger aan mense probeer voordoen nie. Sigbare dra van jou swakhede speel 'n baie groot rol in kommunikasie. Jy kan mense se pyn eers regtig verstaan as jy self pyn verduur het. Die beste poort na 'n ander se pyn is deur jou eie pyn' (Smit 1995:46). Veral jit die apostel Paulus se brief aan die Tessalonisense blyk sy besondere omgee vir die gemeente. Kerkleiding behoort nooit in 'n gees van hoogdrawendheid of outoriteit plaas te vind nie. Dit behoort nie in ' $n$ gees van baasskap plaas te vind nie, maar in 'n gees van dien (Matt 20:26); nie in ' $n$ gees van selfstandige volwassenheid nie, maar van nederige, af- 
hanklike kindwees (Matt 18:1); nie in 'n gees van oorvloedige rykdom, maar van ootmoedige bedelaarskap (Matt 5:3). 'The desire to serve others must be stronger than the desire to lead - so that leadership becomes a means of serving' (Shawchuck \& Heuser 1993:35, kyk veral Stevens \& Collins 1993:116 oor kerkleiers in diensgestalte). Shawchuck \& Heuser (1993:36-57) oordeel dat die volgende noodsaaklik is vir die instandhouding van kerkleiers se spiritualiteit:

* 'n Diepe afhanklikheid van God wat in die besonder tot uitdrukking kom in gebed en besig wees met die Woord van die Here. Dit beteken nie om met die Woord besig te wees om daarmee in die eerste plek by ander mense uit te kom nie, maar by jouself. Toe Luther op ' $n$ stadium gekla het dat hy te besig is, het hy gesê dit is nodig om meer tyd af te staan aan gebed. Met die oog op hulle werksaamhede het die apostels dit nodig geag om aandag aan gebed te gee (Hand 6:4). Gebed in eensaamheid was deel van Jesus Christus se lewe.

* Selfondersoek. Socrates het gesê dat 'the unexamined life is not worh living' (Guthrie soos aangehaal Shawschuck 7 Heuser 1993:37). Volgens Luther behoort 'n gelowige aan die einde van elke dag sy/haar motiewe en aktiwiteite van die dag te ontleed en dit dan in die hande van God te laat (Tappert, in Shawchuck \& Heuser 1993:37). Calvyn sê: sonder kennis van jouself is daar geen kennis van God nie en sonder kennis van God is daar geen kennis van jouself nie (Harper in Shawchuck \& Heuser 1993:37).

* Deurlopende koinonia met ander gelowiges, onder andere die eie huisgesin, 'n vaste klein groep wat dieselfde spitritualiteit as die kerkleier het, en met wie hy/sy 'n bepaalde band het, en met kollegas.

* Waardevolle persoonlike tydsbenutting met die oog op eie ontspanning en geestelike verdieping. Volgens Van de Beek (1996:7) moet die kerkleiers veral vrye tyd hê met die oog op studie en navorsing.

\subsection{Leierskapstyle}

Optrede teenoor ander geskied met 'n bepaalde styl. Nel (1988:70) wys die outoritêre en laises faire style vir kerkleiers af. Daarteenoor stel hy die Christokratiese styl. Dit is die styl waarin ' $n$ leier se optrede deur die Woord en voorbeeld van Christus bepaal word. Blake \& Mouton (in Stevens \& Collins 1993:66) onderskei 4 styltipes in die konsep van persoon en taakgerigtheid, naamlik hoë persoons- of verhoudingsgerigtheid en lae taakgerigtheid, hoë taak- en lae persoonsgerigtheid, lae persoons- en lae taakgerigtheid, hoë persoons- en hoë taakgerigtheid. 
Michiel Van der Merwe (1995:105) onderskei tussen die voorskrywende, oorredende, deelnemende en delegerende styl. Hoewel hoë persoons- en hoë taakgerigtheid in die konsep van Blaken \& Mouton en die deelnemende en delegerende in die konsep van Van der Merwe die ideale styl is, kies Stevens 7 Collins (1993:70) vir 'n buigsame, aanpasbare styl. Die een styl is nie noodwendig beter as die ander nie. Almal is een of ander tyd nodig. Die situasie en die persone daarby betrokke behoort die leier se styl van optrede te bepaal.

\subsection{Visionering en strategiese teologiese beplanning}

'n Gemotiveerde kerkleier met die regte spiritualiteit, het 'n visie. Hy/sy is so aangegryp deur God se doel met die kerk, dat hy/sy hierdie missie sy/haar visie (droom) en die visie van die gemeente maak. 'n Visie in kerklike konteks word bepaal deur die roeping van die kerk, die konkrete situasie van die gemeente en die leefwêreld waarin die gemeente funksioneer. Alle gemeentes werk met 'n visie, maar die meeste gemeentes se visie is uiters vaag en is nog nooit geformuleer nie. 'n Geformuleerde visie is om die volgende redes noodsaaklik (Van der Merwe 1995:39):

* Dit stel gemeentes in staat om deurlopend te evalueer of hulle nog besig is met die mees wesenlike en aktuele sake;

* dit bewaar gemeentes van 'n eensydige na binne gerigtheid en stagnasie;

* veral in tye van onsekerheid, moedeloosheid en uitsigloosheid help 'n visie 'n gemeente om doelgerig koers te hou; end

* dit help om onbetrokke lidmate weer entoe-siasties en betrokke te maak.

Kerkleiers behoort gemeentelede in staat te stel om hulle Godgegewe visie in die gemeenskap waarin hulle funksioneer, te vervul. Hierdie energerende leierskap is alleen moontlik deur die werking van die Heilige Gees. Die Heilige Gees sluit egter nie die mens en sy vermoëns uit nie, maar juis in. Om 'n gemeente se visie planmatig, sinvol en doelgerig te laat realiseer, vereis van kerkleiers kennis en vaardigheid in teologiese strategiese beplanning en bestuur (Nel 1994:21; Hendriks 1992:121; Beukes 1995:806; Coetzee 1996:1; Smit 1995:18; Van der Merwe 1995:78). Kerkleiers moet in staat wees:

* om die gemeentelede deur middel van al die bedieninge te begelei (motiveer) om te besef wat die kerk se roeping is, die begeerte by hulle te wek om self entoesiasties daarby betrokke te wees, ' $n$ visie vir die gemeente te formuleer en dit deurlopend te evalueer; 
* om met behulp van die kerkraad en gemeentelede die gemeente se identiteit te bepaal in die lig van sy huidige geloofshandelinge, sy omgewing, sy geskiedenis en demografie;

*. om realistiese doelwitte vir die gemeente te formuleer;

* om met behulp van al die bedieninge op geïntegreerde wyse die doelwitte te laat realiseer;

* om deurlopend die proses van gemeentebou te lei; en

* om deurlopend te kontroleer in watter mate die doelwitte realiseer en watter aanpassings gemaak moet word.

Bogenoemde beplanningsmodel is een van baie modelle wat vandag in die bestuurswêreld gebruik word. Dit is modelle wat bekend is by lidmate en dit word algemeen aanvaar as bruikbare modelle met die oog op die effektiewe bereiking van doelwitte en die goeie funksionering van organisasies. Praktiese teoloë het reeds wêreldwyd aanvaar dat die benutting van hierdie modelle nie in stryd met die wese van die kerk is nie, dat dit in pas met die denke van die mens van die laat twintigste eeu is en waarskynlik een van die bruikbaarste strategieë is om die kerk te bewaar van stagnasie en om dood te bloei.

\section{AANBEVELINGS}

Op grond van die roeping van die kerk en die hermeneutiek van die een en twintigste eeu se konteks, behoort kerkleiers nie terug te deins of te regresseer nie, maar nuut te dink en dinamies op te tree (Dreyer 1996:188; Müller 1992:27). Die feitlike situasie van die een en twintigste eeu sal van kerkleiers 'n totale nuwe ingesteldheid vra (Coetzee 1996:6; Burger 1994:85). Op die funksionele vlak van kerkwees is veral 'n nuwe gesindheid en vaardigheid ten opsigte van die volgende noodsaaklik:

\section{Kommunikasiestyl}

In plaas van 'n negatiewe anti-alles styl, behoort werklikhede aanvaar te word en positief gewerk te word aan die beste moontlike toekoms vir al die mense van SuidAfrika (Coetzee 1996:7). Die nuwe Suid-Afrikaanse situasie en die kultuur/denkstyle van die een en twintigste eeu moet benut word as geleenthede en nie langer as bedreigings gesien word nie. Die nuwe situasie in Suid-Afrika en die algemene kultuur/ denkpatrone aan die begin van die een en twintigste eeu bied aan die kerk beter geleentheid as ooit om sy missionêre roeping tot uitvoer te bring. 
Die dominante kultuur en denkstyle van die een en twintigste eeu, naamlik die aanvaarding van diversiteit, die strewe na effektiwiteit en die ingesteldheid van omgee vir alle mense, behoort die algemene styl/ingesteldheid van kerkleiers te wees. Inoefening in die akkommodering van diverse standpunte en die benutting van alle kommunikasiestyle behoort vir kerkleiers nie vreemd te wees nie.

'n Algemene neiging tot eksklusiwisme behoort vreemd te wees aan die styl van kerkleiers. Veral empatie teenoor mense wat in die verlede uitgesluit is, soos onder andere vrouens, kinders en mense uit agtergeblewe gemeenskappe, behoort by kerkleiers voor te kom.

Die outoritêre styl wat soms by kerkleiers voorkom, veral by regeer-instansies, behoort plek te makk vir 'n groter gesindheid van omgee. Die van bo-manier van doen, moet vervang word deur 'n manier van saamdoen.

\section{Bedieninge}

Dreyer (1996:184) bepleit heel tereg dat die kerk sal afsien van sy oorbelading van die prediking en dat daar 'n meer gebalanseerde beskouing ten opsigte van al die bedieninge sal bestaan. As die kerk in die een en twintigste eeu sy roeping wil uitvoer, is die volgende aanpassings binne die raamwerk van die etos van die kerk in hierdie verband, wat kerkleiers betref, myns insiens nodig:

* Kerkleiers sal tot die insig gebring moet word dat die roeping van die kerk missionêr is. Hulle sal veral lidmate moet kan begelei om missionêrend in die wêreld besig te wees.

* Kerkleiers sal in staat moet wees om diverse bedieningswyses te benut en moet loskom van die knellende denke dat alle bedieninge in elke gemeente in presies dieselfde vorm gegiet moet wees.

* Kerkleiers sal gemeentelede deur al die bedieninge, maar in die besonder deur afsonderlike goed beplande toerustingsgeleenthede, moet kan begelei om self dienswerk in die wêreld te doen.

* Groepwerk behoort groter klem te kry en veral die besondere dinamika van kleingroepe moet beter benut word. Kerkleiers behoort wyks- en ander groepe in stand te kan hou met die oog op Bybelstudie, omgee en koinonia. 
* Kerkleiers behoort pastorale gesprekke tydens huisbesoek en in die alledaagse omgang met mense te kan benut as besondere geleenthede om vanuit die Woord in die lig van die pastorant se werklikheid naas hom/haar te kom staan.

* Kerkleiers behoort 'n koinoniale klimaat in die gemeente te skep wat in die besonder tot uitdrukking kom in dinamiese eredienste waar voorsiening gemaak word vir alle teikengroepe se behoeftes en alles nie in een vaste vorm gegiet is nie. Sinvolle afwisseling binne breë riglyne, sonder rigiede voorskrifte, behoort moontlik te wees. In die Nederduitsch Hervormde Kerk behoort die argaiese preekstyl plek te maak vir 'n meer neologisties-kommunikatiewe-koinoniale styl en prediking waar, naas die dogma, ook die praktiese uitleef van die geloof 'n regmatige plek kry. Geleenthede behoort geskep te word waar in kleingroepe indringende bespreking van die prediking en ander aktuele sake plaasvind. Lidmate se insigte behoort in die proses van preekmaak benut te word.

* Kerkleiers behoort die insig te hê om te besef dat verkondiging nie net deur woorde plaasvind nie, maar deur woord en daad. Hulle behoort in staat te wees om lidmate te begelei om mense op die markplein en die kerkplein met woord en daad, helpend, helend en vertroostend by te staan.

* Kerkleiers behoort in staat te wees om gemeentelede te lei om bewus te word van hulle gawes en om hierdie gawes in diens van die koninkryk van God te benut.

* Kerkleiers behoort ekumeniese bande in eie omgewing en in breër verband op te bou.

* Kerkleiers moet in staat wees om met hulle voorbeeld, kennis en vaardigheid 'n gemeente op te bou.

* Kerkleiers behoort in staat te wees om in die konteks van die een en twintigsteeeuse milieu die Reformatoriese en Barthiaanse teologie so toe te pas dat dit die mens nie net op kognitiewe, maar ook op affektiewe, konatiewe en handelingsvlak sinvol sal begelei (vgl Van Aarde 1993:6).

* Die spiritualiterit van kerkleiers behoort sodanig te wees dat hulle met woord en daad deur dit wat hulle is, sê en doen, mense na die Here sal lei. 


\section{Literatuurverwysings}

Armour, M C \& Browning, D 1995. Systems-sensitive leadership, empowering diversity without polarizing the church. USA: College press.

Beukes, M J du P 1995. Evaluering van verskillende gemeenteboumodelle met die oog op die daarstelling van 'n eie model vir die Nederduitsch Hervormde Kerk van Afrika. HTS 5.1/3, 806-824.

Bosch, D J 1991. Transforming mission. Paradigm shifts in theology of mission. New York: Orbis Books.

Boshoff, H 1993. Samelewingsveranderinge en die kerk in die negentigerjare: moontlike implikasies. Potchefstroom: Instituut vir Toekomsstudie.

Burger, C 1991. Gemeente en bediening: Die dinamika van 'n Christelike geloofsgemeenskap - nuut gedink oor gemeentes. Pretoria: Lux Verbi.

Callehan, K L 1986. Twelve keys to an effective church: The leaders guide. San Francisco: Harper.

Coetzee, J J 1996. Gemeentebou: 'n Doelgerigte prosesmatige bediening. Ongepubliseerde referaat, Sentrum vir Teologiese Navorsing en Toerusting, Fakulteit Teologie (Afd A), Universiteit van Pretoria.

De Jonh van Arkel, J T 1986. Persoonlikheid en ampsgeskiktheid van die predikant. Praktiese Teologie in Suid-Afrika, 24-38. Pretoria: NG Kerkboekhandel.

Dijkstra-Algra, N \& Vizeede Kruik, 1994. Geloven in de toekomst, deel 1. Drie Bergen: Centrum voor educatie NHK. (Werken aan groei - bouwstenen voor gemeente opbouw.)

Dreyer, T F J 1996. Praktiese kerkwees in die nuwe Suid-Afrika. HTS 52/1, 179189.

Geyser, P A 1996. Predikantwees en spiritualiteit. Die Hervormer 15 November 1996, 6.

Heitink, G 1996. De dominee gaat voorbij. GTT 96/1, 30-35. Kampen: Kok.

Hendriks, J 1992. Strategiese beplanning in die gemeente: die beginsels en praktyk van gemeentevernuwing. Wellington: Hugenote Uitgewers.

Kraemer, H 1960. Het vergeten ambt in de kerk, een theologische fundering. 'S Gravenhage: Boekencentrum.

Lekkerkerker, A F N 1971. Oorsprong en funktie van het ambt. 'S Gravenhage: Boekencentrum.

Louw, D J 1996. Praktiese Teologie in Sosiologiese perspektief - enkele kritiese vrae met die oog op teologiese teorievorming. Praktiese Teologie in Suid-Afrika 11/1, 23-37.

Müller, J C 1991. Pastoral care in post-apartheid South Africa. Praktiese Teologie in Suid-Afrika 6/2, 184-192.

Nel, M 1988. Fases in gemeentebou. Pretoria: NG Kerkboekhandel. 
Nel, M 1994. Gemeentebou. 'Pretoria: Orion.

Shawchuck, N \& Heuser, R 1993. Leading the congregation, caring for yourself while serving the people. Nashville: Abingdon Press.

Smit, A 1995. Nuut gedink oor leierskap in gemeentes: Die begeleiding van 'n christelike geloofsgemeenskap. Kaapstad: Lux Verbi.

Steven, P \& Collins, P 1993. The equiping pastor: a systems approach to congregational leadership. New York: Alban Institute.

Steenkamp, L J S 1996. Kerk en kultuur in 'n postmoderne samelewing. HTS 52/4, 746-764.

Van Aarde, A G 1993. Paradigmaveranderinge: wat word daarmee bedoel? Die Hervormer 86/16, 15 November 1993, 5-6.

Van Biljon, J A 1986. Die predikant en die eise van die tyd. Praktiese Teologie in Suid-Afrika, 39-51. Pretoria: NG Kerkboekhandel.

Van de Beek, A 1996. Spiritualiteit een must voor theologen? GTT 96/1, 3-9. Kampen: Kok.

Van der Merwe, J C \& Beukes, M J du P 1996. Die missionêre gerigtheid van die kerk. HTS 53/3.

Van der Merwe, M 1995. Nuwe treë saam met God: riglyne en programme oorspiritualiteit en gemeentevernuwing. Kaapstad: Lux Verbi.

Van der Westhuizen, H G 1990. Besinning oor die apostolaat in die Nederduitsch Hervormde Kerk. HTS 46/4, 542-566.

Voster, K 1993. Die kerk in 'n nuwe konteks. Ongepubliseerde referaat gehou tydens interkerklike samesprekings. 